\title{
Intellectual Capital and Its Effect on Service Quality of Commercial Bank of Ethiopia: Evidence from SNNPR District
}

\author{
Robel Hilegiyorgis Behaylu ${ }^{* 1}$ Garedew Aweke Gizaw ${ }^{2}$ \\ 1. Lecturer of Department of Management, Dilla University, Dilla, Ethiopia, Postal number: 419 \\ 2. Lecturer of Department of Economics, Dilla University, Dilla, Ethiopia, Postal number: 419,
}

\begin{abstract}
The main purpose of this research is to examine intellectual capital performance of listed district of commercial bank of Ethiopia and its impact on service quality. The researchers used multiple regression analysis to ascertain the extent that intellectual capital components indices affect service quality of the targeted bank district. This study adopts a deduction approach and a quantitative method as the research methodology. Empirical findings of the study showed that human and customer capital have a positive and significant effect on service quality. However, structural capital has statistically weak relationship with service quality.
\end{abstract}

Keywords: intellectual capital, human capital, structural capital, customer capital, service quality

DOI: $10.7176 /$ RJFA/11-3-04

Publication date: February $29^{\text {th }} 2020$

\section{INTRODUCTION}

Nowadays, companies visualize themselves as learning organizations and understand that intellectual capital assets can enhance innovation and play a vital role in improving business performance. The development of resource based view of the firm trigger that both tangible and intangible assets are potential strategic assets and shows the advantages of both tangible and intangible assets. This theory has gained wide acceptance in accounting, economic and management literature as it has been able to provide positive result linkages between resources of firms and measures of performance (Canibano et.al, 2000).

In recent years there has been a growing realization that a company's stock to intangible assets is a key contributor to its capacity to secure a sustainable competitive advantage. Knowledge based intangibles in particular are recognized to be central to the value creation process. Such assets have increasingly been referred to by a new term that of intellectual capital (Masoud et al, 2014) and it is a new issue which has been brought up theoretically in international commercial environment recently (Pourkiani et al., 2014).That's why, its explanation is not same in different studies. It has become significant resource for growth of economy and social prosperity and the wealth of individuals, organizations, regions and countries is associated directly to their intellectual capital utilization (Chao et al., 2015). Hence, it is one of the issues that have been attempted by many researchers for its significance and due to its relative newness (Sharabati et al., 2013).

According to Hsu and Frang (2009), intellectual capital is a company's total capabilities, knowledge, culture, strategy, process, intellectual property, and relational networks which create value or competitive advantages and help a company to achieve its goals. It can be classified as customer capital, process capital, human capital and innovation capital. Typically most firms have three forms of intellectual capital embedded in their people, structures, and customers. These are human capital, structural capital, and relational capital (Rosni, 2011).

According to Mondal \& Ghosh (2014), Businesses particularly service sector require an effective utilization of intellectual capital for their competitive advantage, service quality and customer satisfaction. Among these service sectors, financial institutions especially banks are skill based industries that require this asset mostly. Hence, the competitiveness of banking institutions is mostly influenced by quality of intellectual capital (Shahabadi \& Samari, 2013).

Many studies have been done in the area of intellectual capital and its effect on service quality in banking sector (Kamukama, N., 2013; Mention, A. L., 2011; Al-Musali et al., 2014; Mention, A. L., \& Bontis, N., 2013). However, most existing research studies have focused on investigating the effects of intellectual capital on financial performance of banks and very few studies have addressed its effect on service quality of banking sectors. In addition, earlier studies were conducted primarily in developed countries and mature market economies, which have significant differences in political, social, and economic systems compared to emerging economies like Ethiopia.

Moreover, in spite of having various studies undertaken on intellectual capital by various researchers, none of the studies have particularly addressed the effect of intellectual capital on service quality of commercial bank of Ethiopia, and specifically SNNPR District. Accordingly, this study was carried to examine intellectual capital performance of listed district of commercial bank of Ethiopia and its impact on service quality. 


\section{LITERATURE REVIEW}

\subsection{Resource-based theory}

Resource-based theory (RBT) is a theory developed to analyze the competitive advantage of a company based on the company's resources. According to Firer and Williams (2003), RBT's theory sees a company as a collection of assets or resources and tangible and intangible capabilities. And it assumes that intangible resources are closely related to intellectual capital. Some scholars on Resource-based theory argues that corporate resources are heterogeneous and productive services derived from company resources provide a unique character for each company enough, attractive promotions, and employees and managers who can work professionally some form of resources owned by the company (Astuti and Sabeni, 2005). Intellectual capital is one of the company's resources. Where intellectual capital consists of three resources, namely human capital, structural capital and relational capital power relation). Human capital includes the knowledge, expertise, competence and knowledge of the employee. Structural capital includes corporate organizational culture, information systems and technology adaptation. While relational capital consists of consumer loyalty, service quality and good relationship with suppliers (Tan \& Hancock, 2008).

Intellectual capital is one of the most important resources. If the company can optimize the performance of intellectual capital to the maximum, then the company will have an added value that can provide the value characteristics of company's superiority. So with the added value obtained from the optimal performance of intellectual capital, then the company will be able to have competitiveness against competitors because they have a characteristic of competitive advantage that is only owned by the company.

\subsection{Intellectual Capital}

Intellectual capital although is the critical value driver for the firm to succeed in the fiercely competitive world; it still has many issues remain to be clear regarding its definition. Up to now the definition of intellectual capital is not uniform among different sectors.

According to Abdullah \& Sofian (2012), intellectual capital is intangible asset that comprises of technology, customer loyalty, brand name loyalty, and goodwill etc. On the other hand, Harris, L. (2000) defines intellectual capital as a concept that involves human capital, structural capital and customer capital. He further defines human capital as the package which includes of innovations, knowledge, experiences, and learning capabilities; structural capital as the existing knowledge which can be found within the organization it can be collected, tested, organized, integrated, and the important part can be available for distribution; customer capital is the relationships a firm establish when doing business includes customer, suppliers, it has mainly to do with satisfaction retention, and loyalty.

The most widely used definition of intellectual capital is "knowledge that is of value to an organization." Its main elements are human capital, structural capital, and customer capital. That definition suggests that the management of knowledge (the sum of what is known) creates intellectual capital (Salman, et al., 2012).

\subsubsection{Intellectual Capital Components}

According to Mosavi et al. (2012), intellectual capital component consists of three components, namely human capital, structural capital, and customer capital. There are different views from some researchers on the components that explain the intellectual capital component. In general, according to the majority of research states intellectual capital consists of three components, namely:

\section{Human Capital (HC)}

Human Capital consists of the skills, competencies and abilities of individuals and group (Samad, S., 2013). Boujelbene and Affes(2013) define Human Capital is interpreted as employee values creating potentials depicted in the knowledge, competencies, skills, experiences, abilities and talents of firm's employees and managers. Human capital captures knowledge, professional skills, experience and innovativeness of employees within an organization. It is a combination of knowledge, skills, ability to innovate and the ability to complete tasks, including company value, culture and philosophy (O'Regan et al., 2001). And HC is a resource that comes from the ability and competence of employees owned by a company. Employee competencies and competencies can be enhanced with training programs conducted by the company.

\section{Structural Capital (SC)}

According to Stewart (1997), Structural capital is defined as knowledge assets that are indeed company's' property and includes intellectual property such as patents, copyright and trademarks; processes, methodologies, models; documents and other knowledge artifacts, computer networks and software; administrative systems so forth. It comprises of the knowledge, organizational culture, intellectual procedure, process, philosophy, systems, databases and contracts and explains the structures and processes employees develop and deploy in order to be productive, effective and innovative, Boujelbene and Affes(2013). SC is hardware, software, databases, organizational structures, patents, trademarks and everything else from organizational capabilities that support the productivity of their employees; in other words, everything will be left at the office when employees return. In structural capital there are system technology, hardware, software, operational system company, organization, 
patent, brand, and training company (O'Regan et al., 2001).

\section{Customer capital (CC)}

Customer capital is closely linked to the company's relationship with its customer loyalty and the company's relationships with its partners or suppliers (Shih et al., 2010). The company's relationships with parties outside the company are included in the customer capital. In this case the need for good relations with outsiders such as government, markets, suppliers and customers in order to create loyalty to the company.

\subsection{Intellectual capital and service quality}

The empirical literature reveals that intellectual capital (IC) encourages the business performance and service quality of organizations. There have been prior studies around the world which show relationship between intellectual capital and service quality. Among these studies Goh (2005) investigated the intellectual capital of Malaysian commercial banks based on VAIC ${ }^{\text {TM }}$ model and found that there is significant relationship between service quality and human capital efficiency and also the study shows that HCE has relatively larger contribution in measuring banks performance as compared to structural capital and customer capital.

An empirical study by Joshi et al (2010) also in the same manner the empirical results examined while exploring the Intellectual Capital and banks performance and service quality of Australian owned Banks for the period of 2005-2007 through VAIC TM model. They showed same findings that. Human Capital Efficiency (HCE) is positive and significant to VAIC the evidence also indicates Human Capital has higher explanatory power to enhance the IC performance of Australian banks as compared to other determinants.

A study on banking system in Kuwait by Abdulsalam et al., 2011 show that there is a strong correlation between investment strategies in the intellectual capital and the competitive performance and service quality of companies where most of the relationships were positive. Namasivayam \& Denizci (2006) have analized the impact of human capital in service companies. Authors believe that human features, such as creativity and emotional intelligence of the employees must be adequately evaluated since they affect the perceived value of the consumer. Based on their work, we come to the conclusion that business processes of service companies are closely related to human capital.

\subsection{Proposed Model and Hypothesis}

The model for the study can be presented based on the review of literature on intellectual capital and service quality of banks the framework is shown below;

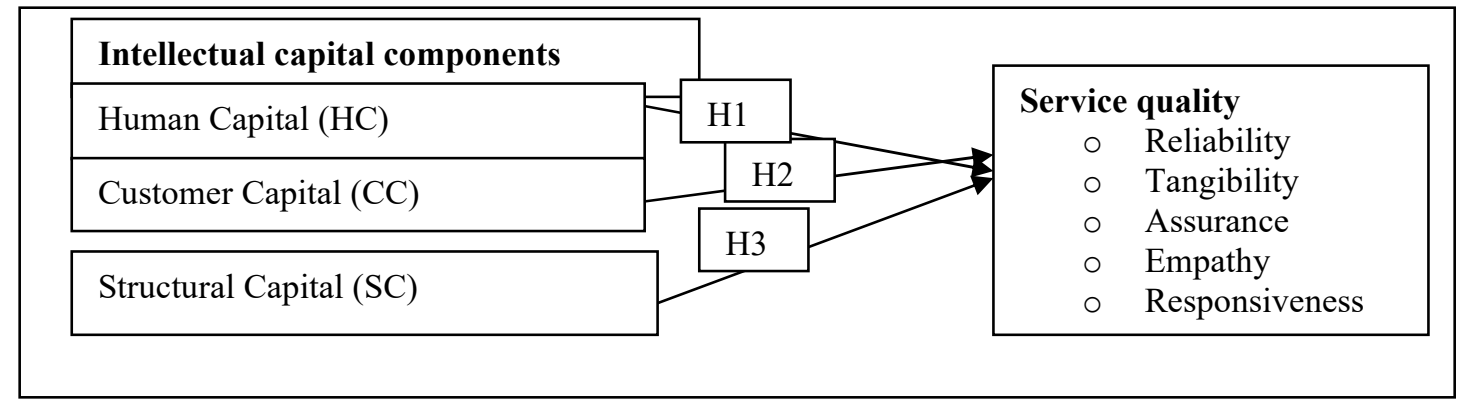

The study proposed the following hypothesis

$\mathrm{H} 1$ : There is a significant positive relationship between the $\mathrm{HC}$ and service quality of banks

$\mathrm{H} 2$ : There is a significant positive relationship between the $\mathrm{CC}$ and service quality of banks

$\mathrm{H} 3$ : There is significant positive relationship between the SC and service quality of banks.

Where; HC (Human Capital), CC (Customer Capital) and SC (Structural Capital)

\section{METHODOLOGY}

\subsection{Research design \& approach}

This research was conducted using quantitative techniques to analyze the primary data in order to test hypotheses of this research. And we follow positivism philosophy and deductive approach because it emphasizes on quantitative method and scientific tools in exploring social reality instead of viewing knowledge is personal experience rather than acquired by objective ways (Wilson, 2010).

\subsection{Sample and data collection}

Nearly 48 commercial bank of Ethiopia branches from SNNPR district were selected as a sample through using judgmental sampling techniques. Branches were selected on the basis of availability of information necessary for conducting the study and the readiness to deliver those data. It has used self-administered five point rating scale questionnaires under survey strategy to gather primary data and a total of 254 questionnaires were prepared and 
distributed to the customers, employee and management bodies of the selected branches.

\subsection{Data analysis}

The collected primary data were analyzed with the help of statistical tools and techniques using SPSS 20. Mainly, the relationship between intellectual capital components and service quality is examined using correlation coefficient. Similarly, the impact of intellectual capital on service quality of the targeted banks was examined through regression analysis. Here, the components of intellectual capital are predictor/independent variables and service quality is dependent variable.

\section{RESULT AND DISCUSSION}

\subsection{Scale Reliabilities}

Reliability is the measure of accuracy and precision of measurement techniques/tools (Cooper \& Schindler, 2008). A measure is said to have a high reliability if it produces similar results under consistent conditions. Cronbach's alpha coefficient is a value between 0 (very low) and 1 (very high) showing internal consistency of items in a scale to measure latent variables.

According to Creswell (2008) regarding as a Cronbach's alpha of .60 or higher to be acceptable, the overall scale in the research was thus reliable, with a Cronbach's alpha coefficient of .8113 for dependent variable indicating that the survey items fit together. The Cronbach's alpha coefficients for the research independent variables ranged between .7165 and .8021 . These show that all factors have acceptable internal consistency.

Table 1: Reliability Analysis result

\begin{tabular}{lcr}
\hline Factors & Number of items & Cronbach's Alpha \\
\hline Service Quality & 10 & .8113 \\
Human Capital & 7 & .8021 \\
Structural Capital & 6 & .7620 \\
Customer Capital & 7 & .7165 \\
\hline
\end{tabular}

\subsection{Multiple Regressions}

Table 2: Results of Multiple Regressions between human capital, structural capital, customer capital and service quality

\begin{tabular}{lllll}
\hline & \multicolumn{2}{c}{ Unstandardized coefficient } & & Sig. \\
\hline \multicolumn{1}{c}{ Model } & B & Std. error & t & \\
\multicolumn{1}{c}{ (Constant) } & .451 & & & \\
Human Capital & .321 & .037 & 9.570 & .001 \\
Customer Capital & .192 & .031 & 6.842 & .000 \\
Structural Capital & .171 & .026 & 5.450 & .020 \\
\hline
\end{tabular}

$\mathrm{R}=.736$

Adjusted R Square $=623$

$\mathrm{R}$ Square $=.625$

Note. Dependent variable: Service Quality

As indicated on the above table 2, out of three components of intellectual capital only two (human capital and customer capital) are significant with service quality at the level of $p<.01$ whereas structural capital is significant at the level of $\mathrm{p}<.05$. Furthermore, multiple regressions identify the relative contribution of each variable and determine the best predictor variables among a set of variables. As revealed on the above table 2, all variables contributed significantly to the service quality. Human capital has the highest contribution to customer loyalty among the independents variables $(\mathrm{B}=.321)$. Other variables were also significantly and positively found to contribute to service quality is customer capital and structural capital respectively.

\subsection{Correlation of Analysis}

According to Vogt (2007), inferential statistical analysis can provide an empirical evidence to accept or reject the hypothesis. The current research tests the null hypothesis of association between the independent variables and the dependent variable. Furthermore, the correlation coefficient was used to describe and quantify the relationship between two variables. Pearson correlations were applied to the examination of the study's hypotheses. Table 3 demonstrates the Pearson's correlation coefficients between the study variables. 
Table 3: Pearson Correlations for independent variables and dependent variable

\begin{tabular}{|c|c|c|c|c|c|}
\hline & & Service quality & $\begin{array}{c}\text { Human } \\
\text { capital }\end{array}$ & $\begin{array}{c}\text { Customer } \\
\text { capital }\end{array}$ & $\begin{array}{c}\text { Structural } \\
\text { capital }\end{array}$ \\
\hline \multirow{3}{*}{ Service quality } & Pearson Correlation & 1 & $.778^{* *}$ & $.654^{* *}$ & $.630^{*}$ \\
\hline & Sig. (2-tailed) & & .001 & .000 & .024 \\
\hline & $\mathrm{N}$ & 254 & 254 & 254 & 254 \\
\hline \multirow{3}{*}{ Human capital } & Pearson Correlation & $.778^{* *}$ & 1 & $.662^{* *}$ & $.703^{* *}$ \\
\hline & Sig. (2-tailed) & .002 & & .001 & .004 \\
\hline & $\mathrm{N}$ & 254 & 254 & 254 & 254 \\
\hline \multirow{3}{*}{ Customer capital } & Pearson Correlation & $.654^{* *}$ & $.662^{* *}$ & 1 & .066 \\
\hline & Sig. (2-tailed) & .000 & .003 & & .622 \\
\hline & $\mathrm{N}$ & 254 & 254 & 254 & 254 \\
\hline \multirow{3}{*}{ Structural capital } & Pearson Correlation & $.630^{*}$ & $.703^{* *}$ & .066 & 1 \\
\hline & Sig. (2-tailed) & .024 & .001 & .622 & \\
\hline & $\mathrm{N}$ & 254 & 254 & 254 & 254 \\
\hline
\end{tabular}

**. Correlation is significant at the 0.01 level (2-tailed).

*. Correlation is significant at the 0.05 level (2-tailed).

The table 3 above shows that service quality and human capital have a strong positive relation .So the service quality and human capital have correlation of 0.778 and are significant $(0.001)$ to each other. Service quality and customer capital also keep competitive strong correlation of 0.654 and are significant $(0.000)$ for both of them. There is a moderate positive relation in between structural capital and service quality with Pearson correlation coefficient of 0.630 and significance value of 0.24 . These two variables are also significant in relation to them but weak in compared to human capital and customer capital.

The result describes that the human capital and customer capital values are more important and significant to service quality than structural capital value of commercial bank of Ethiopia SNNPR district branches.

\section{CONCLUSION}

This study attempted to investigate the relationship between intellectual capital components and service quality of commercial bank of Ethiopia, SNNPR district branches and the components of intellectual capital is described into human capital, customer capital and structural capital that has been previously utilized by similar studies (Firer and Williams, 2003; Williams, 2001; Chen et al., 2005). The empirical regression results of the study reveal that human capital and customer capital have positive and significant relationship with service quality at the level of $\mathrm{p}<0.01$ whereas there is a moderate positive relation in between structural capital and service quality with significance value of 0.24 .

The results of the study also illustrate that human capital and customer capital relatively explain more variation $(\beta=.321 ; \beta=.192$ respectively) and significant contributor to speed up the banks' service quality. From this we can conclude that, the district can get benefit by investing in more human capital (through specialization and division of labor, training and development, further education, experience sharing, etc) and customer capital (through building harmonious relationships with customers, having good brand and trademark protection, etc.), as it shows these intellectual capital components were able to increase firm service quality.

\section{REFERENCE}

Abdullah, D. F., \& Sofian, S. (2012). The relationship between intellectual capital and corporate performance. Procedia-Social and Behavioral Sciences, 40, 537-541.

Abdulsalam, F., Al-Qaheri, H., \& Al-Khayyat, R. (2011). The intellectual capital performance of Kuwaiti banks: an application of VAIC model. ÎBusiness, 3(1), 88-96.

Al-Musali, M. A. K., Ismail, K., \& Izah, K. N. (2014). Intellectual capital and its effect on financial performance of banks: Evidence from Saudi Arabia. Procedia-Social and Behavioral Sciences, 164, 201-207.

Astuti, P., \& Sabeni, A. (2005). Hubungan Intellectual Capital dan Business Performance dengan Diamond Specification. Sebuah Perspektif Akuntansi., Makalah, Simposium Nasional Akuntansi VIII.

Boujelbene, M. A., \& Affes, H. (2013). The impact of intellectual capital disclosure on cost of equity capital: A case of French firms. Journal of Economics Finance and Administrative Science, 18(34), 45-53.

Cañibano, L., Garcia-Ayuso, M., \& Sanchez, P. (2000). Accounting for intangibles: a literature review. Journal of Accounting literature, 19, 102-130.

Chao, C. M., Yu, M. M., \& Wu, H. N. (2015). An application of the dynamic network DEA model: The case of banks in Taiwan. Emerging Markets Finance and Trade, 51(sup1), S133-S151.

Chen, M.-C., Cheng, S.-J. and Hwang, Y. (2005), “An empirical investigation of the relationship between intellectual capital and firms' market value and financial performance", Journal of Intellectual Capital, Vol. 
6 No. 2, pp. 159-76.

Cooper, C. R., \& Schindler, P. S. (2008). Business research methods McGraw-Hill: Boston.

Creswell, J. W., \& Garrett, A. L. (2008). The "movement" of mixed methods research and the role of educators. South African journal of education, 28(3), 321-333.

Das, S. R., Williams, T. G., Drummond, M. L., \& Wilson, A. K. (2010). A QM/QM Multilayer Composite Methodology: The ONIOM Correlation Consistent Composite Approach (ONIOM-ccCA). The Journal of Physical Chemistry A, 114(34), 9394-9397.

Firer, S., \& Williams, S. M. (2003). Intellectual capital and traditional measures of corporate performance. Journal of intellectual capital.

Goh, P. C. (2005). Intellectual capital performance of commercial banks in Malaysia. Journal of intellectual capital.

Harris, L. (2000). A theory of intellectual capital. Advances in Developing Human Resources, 2(1), 22-37.

Hsu, Y. H., \& Fang, W. (2009). Intellectual capital and new product development performance: The mediating role of organizational learning capability. Technological Forecasting and Social Change, 76(5), 664-677.

Joshi, M., Cahill, D., \& Sidhu, J. (2010). Intellectual capital performance in the banking sector. Journal of Human Resource Costing \& Accounting.

Kamukama, N. (2013). Intellectual capital: Firms' hidden source of service quality in the microfinance industry in Uganda. Journal of African Business, 14(3), 150-161.

Mention, A. L. (2011). Exploring voluntary reporting of intellectual capital in the banking sector. Journal of Management Control, 22(3), 279-309.

Mention, A. L., \& Bontis, N. (2013). Intellectual capital and performance within the banking sector of Luxembourg and Belgium. Journal of Intellectual capital.

Mosavi, S. A., Nekoueizadeh, S., \& Ghaedi, M. (2012). A study of relations between intellectual capital components, market value and finance performance. African Journal of Business Management, 6(4), 13961403.

Mondal, A., \& Ghosh, S. K. (2014). Determinants of intellectual capital disclosure practices of Indian companies. Journal of Commerce and Accounting Research, 3(3).

Namasivayam, K., \& Denizci, B. (2006). Human capital in service organizations: identifying value drivers. Journal of Intellectual Capital.

O’Regan, P., O’Donnell, D., Kennedy, T., Bontis, N., \& Cleary, P. (2001). Perceptions of intellectual capital: Irish evidence. Journal of Human Resource Costing and Accounting, 6(2), 29-38.

Pourkiani, M., Sheikhy, A., \& Daroneh, M. S. (2014). Importance and status of intellectual capital in knowledge economy. Indian Journal of Fundamental and Applied Life Sciences, 4, 512-518.

Rosni, A. W. (2011). Mediating Effect of Entrepreneurial Orientation on the Intellectual Capital-Performance Relationship in the Malaysian Banking Sector (Doctoral dissertation, Universiti Utara Malaysia).

Salman, R. T., Mansor, M., Babatunde, A. D., \& Tayib, M. (2012). Impact of intellectual capital on return on asset in Nigerian manufacturing companies. Interdisciplinary journal of research in business, 2(4), 21-30.

Samad, S. (2013). Assessing the contribution of human capital on business performance. International Journal of Trade, Economics and Finance, 4(6), 393.

Sharabati, A. A. A., \& Nour, A. N. I. (2013). The Relationship between Human Capital Development and University's Business Performance. European Journal of Business and Management.

Shih, K. H., Chang, C. J., \& Lin, B. (2010). Assessing knowledge creation and intellectual capital in banking industry. Journal of intellectual capital.

Shahabadi, A., \& Samari, H. (2013). The effect of economic freedom on bank performance.

Shih, K. H., Chang, C. J., \& Lin, B. (2010). Assessing knowledge creation and intellectual capital in banking industry. Journal of intellectual capital.

Stewart, T. A. (1997). A satisfied customer isn't enough. Fortune, 136(2), 112-113.

Tan, H. P., Plowman, D., \& Hancock, P. (2008). The evolving research on intellectual capital. Journal of intellectual capital.

Vogt, W. P. (2007). Quantitative research methods for professionals. Allyn \& Bacon.

Williams, S. M. (2001). Is intellectual capital performance and disclosure practices related?. Journal of Intellectual capital. 